\title{
Pengaruh Model Learning Start With A Question Berbasis Eksperimen Sederhana terhadap Pemahaman Konsep Fisika Siswa Kelas X Man 2 Model Palu
}

\author{
Siti Vani, H.Fihrin, dan Syamsu \\ vanisiti@gmail.com \\ Program Studi Pendidikan Fisika FKIP Universitas Tadulako \\ Jl. Soekarno Hatta Km. 9 Kampus Bumi Tadulako Tondo Palu - Sulawesi Tengah
}

\begin{abstract}
Abstrak - Penelitian ini bertujuan untuk mengetahui ada tidaknya perbedaan pemahaman konsep fisika antara siswa yang diajarkan model Learning Start with a Question berbasis eksperimen sederhana dengan siswa yang diajarkan model Learning Start with a Question tanpa eksperimen sederhana di kelas X MAN 2 Model Palu. Penelitian ini merupakan penelitian eksperimen kuasi menggunakan desain the non ekuivalen prestest-postest design. Sampel dipilih dengan menggunakan teknik purposive sampling dan menghasilkan kelas X MIA 4 sebagai kelas eksperimen ke-1 dan kelas X MIA 3 sebagai kelas eksperimen ke-2. Instrumen yang digunakan berupa tes pemahaman konsep fisika dalam bentuk tes esai berjumlah 8 soal yang telah divalidasi melalui validitas ahli. Berdasarkan hasil pengolahan data, diperoleh rerata skor pretest pemahaman konsep fisika siswa kelas eksperimen ke-1 adalah 9.40 dengan standar deviasi 1.96, untuk rerata skor posttest adalah 25.77 dengan standar deviasi 2,86. Untuk kelas eksperimen ke-2 diperoleh rerata skor pretest 9.59 dengan standar deviasi 2.26, sedangkan untuk rerata skor posttest adalah 21,50 dengan standar deviasi 2,64. Analisis data tes dilakukan dengan teknik statistik uji-t satu pihak untuk menguji perbedaan rerata skor pemahaman konsep fisika siswa dengan taraf signifikan $a=0,05$. Diperoleh nilai hasil $t_{\text {hitung }}=5.53$ dan $t_{\text {tabel }}=1.68$. Ini berarti bahwa nilai thitung berada diluar daerah penerimaan $\mathrm{H}_{0}$. Sehingga dapat disimpulkan bahwa, ada perbedaan pemahaman konsep fisika antara siswa yang diajarkan model Learning Start with a Question berbasis eksperimen sederhana dengan siswa yang diajarkan model Learning Start with a Question tanpa eksperimen sederhana di kelas X MAN 2 Model Palu.
\end{abstract}

Kata Kunci: Learning Start with a Question, Eksperimen sederhana, Pemahaman konsep fisika

\section{PENDAHULUAN}

Belajar pada hakikatnya adalah proses interaksi terhadap semua situasi yang ada di sekitar individu. Belajar dapat dipandang sebagai proses yang diarahkan kepada tujuan dan proses berbuat melalui berbagai pengalaman. Belajar merupakan proses melihat, mengamati, dan memahami sesuatu. Sedangkan pembelajaran adalah proses interaksi peserta didik dengan guru dan sumber belajar pada suatu lingkungan belajar [1].

Fisika adalah ilmu yang mempelajari tentang fenomena alam, baik secara kualitatif maupun kuantitatif dengan menggunakan matematika. Selain itu, fisika juga mempelajari strukur materi dan interaksinya untuk memahami sistem alam dan sistem buatan (teknologi). Setelah mempelajari fisika, diharapkan siswa dapat memahami dan menguasi konsepkonsepnya serta dapat menerapkan dalam kehidupan sehari-hari. Oleh karena itu proses pembelajaran fisika harus dilaksanakan pada tahapan dimana siswa lebih ditekankan untuk berperan dalam membangun pengetahuannya. Dengan demikian siswa akan lebih memahami tentang apa yang dipelajarinya dengan baikn [2].
Model learning start with a question adalah pembelajaran yang membuat siswa belajar secara aktif dengan membuat mereka bertanya tentang materi pelajaran sebelum ada penjelasan dari guru. Pembelajaran yang menggunakan model LSQ, membuat siswa menjadi siap memulai pelajaran, karena siswa belajar terlebih dahulu sehingga siswa memiliki sedikit gambaran mengenai materi pelajaran, selain itu LSQ mampu memfasilitasi untuk berani mengajukan pertanyaan dari bagian materi pelajaran yang siswa tidak pahami, sehingga membuat siswa mengingat materi pelajaran lebih lama [3].

Model Learning Start with a Question (LSQ) adalah pembelajaran aktif yang dimulai dari suatu pertanyaan. Pembelajaran lebih efektif jika siswa tersebut lebih aktif mencari pola dari pada menerima saja. Meodel ini merangsang siswa untuk bertanya tentang materi pelajarannya terlebih dahulu, sehingga akan timbul pertanyaan- pertanyaan dari siswa mengenai topik yang tidak bisa mereka pahami sendiri, dari pertanyaan siswa itulah guru memulai menerangkan materi pelajaran kepada siswa. Jika tidak ada pertanyaan-pertanyaan dari siswa mengenai topik yang diajarkan, 
p-ISSN 2338-3240, e-ISSN 2580-5924

maka guru harus memberikan pertanyaan kepada siswa [4].

Model Learning Start with a Question merupakan salah satu model pembelajaran yang dapat membuat siswa aktif dan terus bertanya daripada hanya menerima apa yang disampaikan guru. Kemampuan yang dapat dicapai siswa melalui model $L S Q$ antara lain kemampuan penerimaan dengan mengikuti dan mematuhi suatu instruksi, berpatisipasi dalam diskusi melalui kegiatan membuat dan menanggapi suatu pertanyaan, menilai dengan mendukung atau menentang suatu gagasan, berembug bersama kelompok dengan merumuskan dan mendiskusikan permasalahan, dan kemampuan mencari penyelesaian suatu masalah [5].

Melalui model Learning Start with a Question dapat menjadikan siswa aktif dalam mencari tahu materi yang dipelajari dan terlibat langsung dalam pembelajaran yaitu dengan cara mengajukan pertanyaan mengenai materiatau konsep yang tidak dipahami. Cara menciptakan pola belajar aktif pada siswa adalah dengan merangsang siswa untuk bertanya tentang materi pelajaran tanpa penjelasan dari guru terlebih dahulu [6].

Penelitian yang telah dilakukan oleh peneliti sebelumnya, dalam hasil penelitiannya mengungkapkan pengetahuan yang diperoleh siswa melalui model learning start with a question memberikan pengalaman baru terhadap proses belajar siswa. Siswa dapat memahami apa yang dipelajarinya, bukan hanya sekedar tahu atau sekedar hafal rumusrumus di buku. Melalui pembelajaran aktif di mata pelajaran fisika, siswa mendapatkan pengetahuan yang bermakna dan sulit untuk dilupakan. Model learning start with a question ini, siswa dituntut untuk aktif dalam pembelajaran. Aktif dalam bertanya, menjawab, berdiskusi, menyampaikan pendapat dan bekerja sama [7].

Berbeda dari penelitian tersebut. Pada penelitian ini, peneliti menggunakan model Learning Start with a Question dengan berbasis eksperimen sederhana. Melalui kegiatan eksperimen sederhana siswa berperan langsung dalam pembelajaran dan berusaha menemukan konsep yang dituju, sehingga pemahaman konsep fisika siswa dapat meningkat.

Metode eksperimen adalah cara penyajian bahan pelajaran dimana siswa melakukan percobaan dengan mengalami dan membuktikan sendiri sesuatu yang dipelajari. Dalam proses belajar mengajar dengan metode eksperimen, siswa diberi pengalaman untu mengalami sendiri tentang suatu obyek menganalisis, membuktikan, dan menarik kesimpulan tentang suatu obyek keadaan.

\section{METODE PENELITIAN}

Penelitian yang digunakan adalah jenis penelitian dengan rancangan eksperimen kuasi (quasi-experimental design)

Desain penelitian yang digunakan yaitu the nonequivalent pretest-posttest design. Desain penelitian yang digunakan dapat dilukiskan seperti pada Tabel 1. [8].

\begin{tabular}{cccc}
\multicolumn{4}{c}{ TABEL 1 DESAIN PENELITIAN } \\
\hline Kelompok & Pra tes & Perlakuan & Pascates \\
\hline Eksperimen 1 & $\mathrm{O}_{1}$ & $\mathrm{X}_{1}$ & $\mathrm{O}_{2}$ \\
Eksperimen 2 & $\mathrm{O}_{1}$ & $\mathrm{X}_{2}$ & $\mathrm{O}_{2}$ \\
\hline
\end{tabular}

Keterangan:

$\mathrm{X}_{1}$ : Model Learning Start with a Question Berbasis Eksperimen Sederhana

$\mathrm{X}_{2}$ :Model Learning Start with a Question Tanpa Eksperimen Sederhana

$\mathrm{O}_{1}$ :Tes awal

$\mathrm{O}_{2}$ :Tes akhir

Penelitian dilakukan di MAN 2 Model Palu. Populasi dalam penelitian ini adalah seluruh kelas X MAN 2 Model Palu tahun pelajaran 2015/2016 yang terdiri dari 6 kelas. Sampel dalam penelitian ini adalah kelas X MIA 4 yang berjumlah 22 siswa dan $X$ MIA 3 yang berjumlah 22 siswa. Teknik pengumpulan sampel yang digunakan adalah purposive sampling, yaitu teknik penentuan sampel dengan pertimbangan tertentu.

Instrumen yang digunakan dalam penelitian ini adalah tes esai dan rubrik penilaian. Tes esai untuk melihat pemahaman konsep fisika siswa. Proses analisis tes dilakukan melalui validitas ahli yang ditekankan pada validitas isi dan validitas kontruksi, yang kemudian dengan menganalisis data hasil penelitian menggunakan uji normalitas, uji homogenitas dan uji hipotesis.

\section{HASIL DAN PEMBAHASAN}

\section{A. Hasil Penelitian}

Suatu instrumen dikatakan valid apabila instrument tersebut dapat mengukur apa yang seharusnya diukur. Berdasarkan hasil validitas ahli, jumlah soal yang diajukan sebanyak 9 nomor dan yang valid sebanyak 8 nomor. Soal yang valid dengan kriteria valid tertinggi terdapat pada penggunaan bahasa, kebenaran konsep, kesesuaian isi, dan pemaknaan kalimat. Pada soal pretest dan posttest dibuat sedikit berbeda, dimana perbedaannya terletak pada jumlah soal yang diberikan. Untuk jumlah 
p-ISSN 2338-3240, e-ISSN 2580-5924

soal pretest sebanyak 5 nomor dan untuk soal posttest sebanyak 8 nomor.

Preetest digunakan untuk mengetahui kemampuan awal siswa sebelum mengikuti pembelajaran. Data preetest terdiri dari kelas eksperimen 1 dan kelas eksperimen 2 yang masing- masing berjumlah 22 siswa. Hasil pengolahan data preetest dan posttest untuk masing-masing kelas, yaitu kelas eksperimen 1 dan kelas eksperimen 2, diperoleh nilai maksimum, nilai minimum, nilai rata-rata dan simpangan baku seperti terlihat pada Tabel 2 .

TABEL 2 DESKRIPSI SKOR TES HASIL BELAJAR FISIKA UNTUK KELAS EKSPERIMEN DAN KELAS KONTROL

\begin{tabular}{lcccc}
\hline \multirow{2}{*}{ Uraian } & Preetest & \multicolumn{3}{c}{ Posttest } \\
\cline { 2 - 5 } & Eksp 1 & Eksp 2 & Eksp 1 & Eksp 2 \\
\hline $\begin{array}{l}\text { Sampel } \\
(\mathrm{n})\end{array}$ & 22 & 22 & 22 & 22 \\
$\begin{array}{l}\text { Nilai } \\
\text { maksimum }\end{array}$ & 15 & 14 & 30 & 26 \\
$\begin{array}{l}\text { Nilai } \\
\text { minimum }\end{array}$ & 6 & 5 & 21 & 17 \\
$\begin{array}{l}\text { Skor rata- } \\
\text { rata }\end{array}$ & 9,40 & 9,59 & 25,77 & 21,50 \\
$\begin{array}{l}\text { Standar } \\
\text { deviasi }\end{array}$ & 1,96 & 2,26 & 2,86 & 2,64 \\
\hline
\end{tabular}

Uji normalitas pada penelitian ini menggunakan uji Chi-kuadrat dengan kriteria penerimaan $\mathrm{X}^{2}$ Hitung $<\mathrm{X}^{2}$ tabel, taraf signifikansi a $=0,05$ dan derajat kebebasan $\mathrm{dk}=\mathrm{k}-3$. Berdasarkan hasil perhitungan untuk posttest nilai $\chi^{2}$ hitung untuk kelas eksperimen 1 adalah sebesar 3,33 dan untuk kelas eksperimen 2 sebesar 1,79 dengan $\chi^{2}$ tabel sebesar 5,99. Data tersebut disajikan pada Tabel 3.

TABEL 3 HASIL UJI NORMALITAS POSTTEST KELAS EKSPERIMEN DAN KELAS KONTROL

\begin{tabular}{|c|c|c|c|c|}
\hline \multirow[b]{2}{*}{ No } & \multirow[b]{2}{*}{ Kelas } & \multicolumn{2}{|r|}{ Nilai } & \multirow[b]{2}{*}{ Keputusan } \\
\hline & & $\begin{array}{l}\text { Nilai } \\
X^{2} \text { Hitung }\end{array}$ & $\begin{array}{l}X^{2} \\
(a \\
0,05)\end{array}=$ & \\
\hline 1 & $\begin{array}{l}\text { Kelas } \\
\text { Eksperimen } 1\end{array}$ & 3,33 & 5,99 & $\begin{array}{l}\text { Terdistribusi } \\
\text { normal }\end{array}$ \\
\hline 2 & $\begin{array}{l}\text { Kelas } \\
\text { Eksperimen } 2\end{array}$ & 1,79 & 5,99 & $\begin{array}{l}\text { Terdistribusi } \\
\text { normal }\end{array}$ \\
\hline
\end{tabular}

Berdasarkan hasil uji normalitas pada Tabel 3 diketahui nilai $\mathrm{X}^{2}$ Hitung $<\mathrm{X}^{2}$ tabel sehingga dapat disimpulkan keduanya berasal dari populasi yang terdistribusi normal.

Uji homogenitas pada penelitian ini menggunakan uji statistik Fisher (Uji F) dengan taraf signifikansi $a=0,05$. Uji homogenitas dilakukan untuk melihat apakah data berasal dari varians yang sama atau tidak.
TABEL 4 HOMOGENITAS DUA VARIANS TES AKHIR (POSTTEST) KELAS EKSPERIMEN DAN KELAS KONTROL.

\begin{tabular}{|c|c|c|c|c|c|}
\hline $\begin{array}{l}\mathrm{N} \\
\mathrm{O} .\end{array}$ & Kelas & $\begin{array}{l}\text { Nilai } \\
\text { varians }\end{array}$ & $\begin{array}{l}\text { Varians } \\
\text { hitung }\end{array}$ & $\begin{array}{l}\text { Nilai F } \\
\text { table } \\
(a= \\
0,05)\end{array}$ & Keputusan \\
\hline 1 & Ekperimen 1 & 7,58 & \multirow[b]{2}{*}{1,37} & \multirow[b]{2}{*}{2,03} & \multirow{2}{*}{$\begin{array}{l}\text { Kedua } \\
\text { data } \\
\text { homogen }\end{array}$} \\
\hline 2 & Ekperimen 2 & 5,52 & & & \\
\hline
\end{tabular}

Berdasarkan hasil uji homogenitas pada Tabel 4 dengan taraf signifikansi $(a=0,05)$, dari data tersebut terlihat bahwa Fhitung lebih kecil dari Ftabel, maka berdasarkan kriteria pengambilan keputusan dapat disimpulkan bahwa tidak terdapat perbedaan varians antara kelas eksperimen 1 dan kelas eksperimen 2 atau dengan kata lain varians antara kelas eksperimen 1 dan kelas eksperimen 2 adalah sama atau homogen.

Uji hipotesis dilakukan setelah diperoleh bahwa data hasil pemahaman konsep antara kelas ekperimen 1 dan ekperimen 2 berdistribusi normal dan homogen. Uji ini digunakan untuk memastikan apakah hipotesis yang dilakukan dapat diterima atau tidak. Uji t tersebut diperoleh berdasarkan data tes akhir. Dapat dilihat pada Tabel 5.

TABEL 5 UJI BEDA RATA-RATA (DUA PIHAK) TES AKHIR KELAS EKSPERIMEN

\begin{tabular}{|c|c|c|c|c|c|}
\hline No. & Kelas & $\begin{array}{l}\text { Nilai } \\
\text { rata- } \\
\text { rata } \\
(\bar{X})\end{array}$ & t hitung & $\begin{array}{c}\mathrm{t} \\
\text { table }\end{array}$ & Keputusan \\
\hline 1 & Kelas Eksp 1 & 25,77 & \multirow[b]{2}{*}{5,53} & \multirow[b]{2}{*}{1,68} & $\mathrm{H}_{1}$ \\
\hline 2 & Kelas Eksp 2 & 21,50 & & & \\
\hline
\end{tabular}

Uji $t$ yang digunakan untuk hipotesis ini adalah uji-t dua pihak. Uji ini digunakan untuk memastikan apakah hipotesis yang diajukan dapat diterima atau ditolak.

Kriteria $\mathrm{H}_{0}$ diterima jika thitung $<t_{\text {tabel }}$ dan $\mathrm{dk}$ $=\left(\mathrm{n}_{1}+\mathrm{n}_{2}-2\right)=22+22-2=42$ pada taraf nyata $a=0,05$, untuk harga $t$ lainnya $\mathrm{H}_{0}$ ditolak. Dari daftar distribusi diperoleh tabel $=$ 1,68 sedangkan dari hasil perhitungan uji-t diperoleh nilai thitung $=5,53$ yang berada di luar daerah penerimaan $\mathrm{H}_{0}$. Hal ini berarti thitung $>$ tabel $=5,53>1,68$; dengan demikian $\mathrm{H}_{0}$ di tolak dalam taraf nyata $\mathrm{a}=0,05$ dan $\mathrm{H}_{1}$ diterima. Dengan demikian $\mathrm{H}_{0}$ ditolak dan $\mathrm{H}_{1}$ diterima. Dari data tersebut dapat disimpulkan bahwa terdapat perbedaan pemahaman konsep antara siswa yang diajar menggunakan model Learning Start with a Question berbasis eksperimen sederhana dengan siswa yang diajar menggunakan model Learning Start with a Question tanpa eksperimen sederhana di kelas X MAN 2 Model Palu. 


\section{B. Pembahasan}

Penelitian ini bertujuan untuk mengetahui ada tidaknya perbedaan pemahaman konsep fisika siswa yang telah diajarkan model learning start with a question berbasis eksperimen sederhana yaitu kelas eksperimen 1, dengan siswa diajarkan learning start with a question tanpa eksperimen sederhana yaitu kelas eksperimen 2. Pada awal penelitian kedua kelas terlebih dahulu diberikan pretest, tes awal (pretest) digunakan untuk mengetahui pengetahuan awal siswa sebelum diberi perlakuan. Sedangkan tes akhir (posttest) diberikan untuk mengetahui kemampuan akhir siswa di kedua kelas dan sebagai data analisis penelitian, yang selanjutnya digunakan sebagai pembanding untuk melihat apakah terdapat perbedaan pemahaman konsep antara kedua kelas tersebut pada materi fluida statis.

Berdasarkan hasil pengolahan data yang telah dilakukan, diketahui bahwa kemampuan awal siswa masih rendah, hal ini dapat dilihat dari pemberian tes awal (pretest) pada kelas eksperimen 1 (X MIA 4) dengan skor rata-rata sebesar 9,40 sedangkan skor rata-rata pada kelas eksperimen 2 (X MIA 3) adalah 9,59. Untuk pemberian tes akhir (posttest) pencapaian skor rata-rata pada kelas eksperimen 1 (X MIA 4) sebesar 25,77 sedangkan pada kelas Eksperimen 2 (X MIA 3) sebesar 21,50. Dari hasil penelitian ini dapat dilihat bahwa skor rata-rata kelas eksperimen 1 lebih tinggi dari pada kelas eksperimen 2 . Kemudian berdasarkan uji normalitas posttest, bahwa data yang diperoleh terdistribusi normal dan mempunyai varians yang homogen. Dari hasil penelitian ini, dapat diketahui bahwa dengan memberikan perlakuan yang berbeda pada kelas eksperimen 1 dan kelas eksperimen 2, akan memperoleh kemampuan pemahaman konsep yang berbeda. Pada kelas eksperimen 1 diberi perlakuan dengan model learning start with a question berbasis eksperimen sederhana sedangkan pada kelas eksperimen 2 diberi perlakuan dengan model learning start with a question tanpa eksperimen sederhana.

Perlakuan dengan model learning start with a question yang diberikan pada kedua kelas adalah sama, akan tetapi model LSQ yang diterapkan pada kelas eksperimen 1 , berbasis eksperimen sederhana sedangkan kelas eksperimen 2 hanya diterapkan model LSQ dengan diskusi kelompok.

Pemahaman konsep siswa pada kelas eksperimen 1 lebih baik dari pada kelas eksperimen 2. Sebelum kelas eksperimen 1 diberi perlakuan para siswa memberikan jawaban yang salah dan tanpa alasan yang ilmiah. Setelah diberi perlakuan, sebagian besar siswa mampu menjawab soal dengan tepat dan dengan alasan yang ilmiah. Sedangkan pada kelas eksperimen 2, tidak banyak siswa yang dapat menjawab soal dengan tepat. Berikut daftar hasil persentase pemahaman konsep fisika siswa kelas eksperimen 1 dan kelas eksperimen 2.

\begin{tabular}{|c|c|c|}
\hline \multirow[t]{2}{*}{ Konsep } & \multicolumn{2}{|c|}{ \% Pemahaman Konsep Siswa } \\
\hline & Eksperimen 2 & Eksperimen 1 \\
\hline Tekanan Hidrostatis & $59,09 \%$ & $78,40 \%$ \\
\hline $\begin{array}{l}\text { Hukum Pascal (prinsip } \\
\text { kerja hukum pascal pada } \\
\text { pompa hidrolik) }\end{array}$ & $93.18 \%$ & $100 \%$ \\
\hline 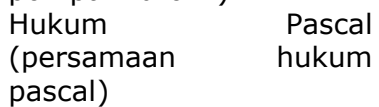 & $59,09 \%$ & $76,13 \%$ \\
\hline Hukum Archimedes & $71,59 \%$ & $79,54 \%$ \\
\hline $\begin{array}{l}\text { Hukum Archimedes } \\
\text { (mengapung, tenggelam } \\
\text { dan melayang) }\end{array}$ & $80,68 \%$ & $87,50 \%$ \\
\hline $\begin{array}{l}\text { Tegangan Permukaan } \\
\text { (peristiwa kapilaritas zat } \\
\text { cair) }\end{array}$ & $65,90 \%$ & $79,54 \%$ \\
\hline Tegangan Permukaan & $59,09 \%$ & $76,13 \%$ \\
\hline Tegangan Permukaan & $36,36 \%$ & $69,31 \%$ \\
\hline
\end{tabular}

Menurut Arikunto persentase pemahaman konsep di kategorikan baik berkisar 76\%$100 \%$, di kategorikan cukup berkisar 56\%-75\% dan kurang berkisar $0-55 \%$. Pada kelas eksperimen 1 terdapat 2 soal memiliki persentase yang cukup dan 6 soal dapat di kategorikan baik [9].

Bedasarkan Tabel 6, dapat dilihat bahwa pemahaman konsep fisika untuk kelas eksperimen 1 lebih baik di bandingkan dengan kelas Eksperimen 2. Dari 8 soal pemahaman konsep yang diberikan, siswa pada kelas eksperimen 1 untuk persentase pemahaman konsepnya pada semua soal lebih tinggi di bandingkan dengan kelas eksperimen 2 . Hal ini disebabkan karena perbedaan perlakuan yang diberikan pada kedua kelas, yang dapat dilihat pada fase pembelajarannya.

Perbedaan fase pembelajaran pada kelas eksperimen 1 dan eksperimen 2, terdapat pada fase 5 yaitu aktifitas dilakukan oleh kelompok. Untuk kelas eksperimen 1 pada fase ini, guru membagikan LKS dan LDS serta membimbing siswa dalam melakukan eksperimen sederhana. Setelah melakukan eksperimen, siswa mendiskusikan hasil eksperimen dan pertanyaan yang terdapat dalam LDS. Sedangkan pada kelas eksperimen 2, guru hanya membagikan LDS yang berisi pertanyaan 
konsep, dan siswa melakukan diskusi kelompok.

Siswa pada kelas eksperimen 1, melakukan eksperimen sederhana, dengan menggunakan metode eksperimen siswa diberikan kesempatan untuk mengalami sendiri, mengikuti suatu proses, mengamati suatu objek, menganalisis, membuktikan dan menarik kesimpulan sendiri mengenai suatu objek keadaan atau proses tertentu. Sedangkan pada kelas eksperimen 2, siswa hanya melakukan diskusi kelompok melalui lembar diskusi yang berisikan pertanyaan-pertanyaan konsep.

Berdasarkan hasil uji hipotesis diketahui bahwa setelah diberikan perlakuan dengan model Learning Start with a Question berbasis eksperimen sederhana menunjukkan terdapat perbedaan hasil pemahaman konsep fisika dengan kelas yang menggunakan model Learning Start with a Question tanpa eksperimen sederhana. Hal ini disebabkan karena pada pembelajaran dengan menggunakan model Learning Start with a Question berbasis eksperimen sederhana siswa lebih berperan aktif dan dituntut untuk menemukan sendiri konsep fisika dengan melakukan pengamatan langsung melalui eksperimen sederhana yang dilakukan.

Metode eksperimen membuat siswa lebih memahami konsep fisika sebab dengan eksperimen siswa menemukan bukti kebenaran dari teori sesuatu yang sedang dipelajarinya. Dalam proses pembelajaran dengan menggunakan metode eksperimen siswa diberikan kesempatan untuk mengalami sendiri, mengikuti suatu proses, mengamati suatu objek, menganalisis, membuktikan dan menarik kesimpulan sendiri mengenai suatu objek keadaan atau proses tertentu.

Penelitian ini didukung oleh penelitian sebelumya, diketahui bahwa hasil belajar kimia siswa yang belajar menggunakan model LSQ lebih baik daripada siswa yang belajar menggunakan model SRL [10].

Hal yang berbeda dari penelitan ini dibandingkan dengan penelitan sebelumnya, adalah model Learning Start with a Question dibuat berbasis eksperimen sederhana, sehingga membuat model Learning Start with a Question lebih menarik lagi. penelitian ini juga di dukung oleh penelitian sebelumnya. Berdasarkaan hasil penelitiannya, diketahui bahwa penerapan metode eksperimen mempunyai pengaruh yang lebih baik terhadap prestasi belajar siswa pada materi pokok perpindahan kalor [11].

\section{KESIMPULAN DAN SARAN}

Berdasarkan hasil penelitian dan analisis data yang diperoleh, maka dapat disimpulkan bahwa terdapat perbedaan pemahaman konsep fisika siswa yang diberi perlakuan model Learning Start with a Question berbasis eksperimen sederhana dengan siswa yang diberi perlakuan model Learning Start with a Question tanpa eksperimen sederhana di kelas $X$ MAN 2 Model Palu. Hal ini dapat dilihat dari hasil pengujian hipotesis, thitung $>$ tabel atau 5,53 > 1,68 atau $\mathrm{H}_{0}$ ditolak dan $\mathrm{H}_{1}$ diterima, yang berarti terdapat perbedaan pemahaman konsep siswa diberi perlakuan model Learning Start with a Question berbasis eksperimen sederhana dengan perlakuan model Learning Start with a Question tanpa eksperimen sederhana.

Berdasarkan hasil penelitian yang dilakukan, maka peneliti menyarankan kepada guru maupun calon guru yang ingin menggunakan model Learning Start with a Question berbasis eksperimen sederhana. Sebaiknya, dalam menggunakan model pembelajaran yang terpenting adalah keaktifan siswa dan motivasi belajarnya, sehingga merupakan tugas guru untuk meningkatkan hal tersebut. Peneliti mengharapkan adanya penelitian lain yang menggunakan model Learning Start with a Question dengan menggunakan metodemetode yang lebih inofatif.

\section{DAFTAR PUSTAKA}

[1] Sitorus, F . 2014. Perbedaan Hasil Belajar Siswa Menggunakan Model Pembelajaran LSQ dengan QSH di kelas X SMA Swasta Yapim Medan pada Materi Pokok Virus. Skripsi Program Studi Biologi Mipa Universitas Negeri Medan.

[2] Roswati, T. 2014. Meningkatkan Hasil Belajar Siswa dengan Menggunakan Model Pembelajaran Learning Start with a Question (LSQ) Kompetensi Dasar Analisis Vektor untuk Gerak Mata Pelajaran Fisika di Kelas XI IPA SMAN 3 Medan. Jurnal Teknologi Pendidikan. 7 (2), (2014), 201-210.

[3] Zaini. H, Munthe. B, dan Aryani.S. 2008. Strategi Pembelajaran Aktif. Yogyakarta: Pustaka Insan Madani.

[4] Yenni, F . 2012. Metode Aktif Learning Tipe LSQ pada Pembelajaran Matematika Di SMPN 33 Padang. Jurnal Pendidikan Matematika, 1, (1) (2012), 70-74.

[5] Silberman. M. 2007. Active Learning 101 Cara Belajar Siswa Aktif. Yogyakarta : Pustaka Insan.

[6] Rangga, E . 2010. Upaya Menigkatkan Kemampuan Afektif Siswa Kelas $X-9$ SMAN 3 Surakarta melalui Strategi LSQ Diseratai Modul Hasil Penelitian Zygomycotina. Biology FKIP Sebelas Maret University, $1,(1)$ (2010).

[7] Adhy. T. 2015. Upaya Peningkatan Minat dan Hasil Belajar Siswa Melalui Model LSQ pada Siswa Kelas XI SMAN I Kendal. UNNES Physics Education Journal. 4, 3 (2015)

[8] Sugiyono. (2010). Metode Penelitian Pendidikan: Pendekatan Kualitatif, kuantitatif dan R\&D. Bandung : CV Alfabeta. 
[9] Rahmaniar. 2015. Pengaruh Pendekatan Guided Discovery Inquiry Laboratory Lesson terhadap Pemahaman Konsep Fisika Siswa Kelas VII SMP Negeri 18 Palu. Skripsi. Universitas Tadulako : tidak diterbitkan

[10]Susatyo, E. 2009. Penggunaan Model Learning start With A Question Dan Self Regulated Learning Pada
Pembelajaran Kimia. Jurnal Inovasi Pendidikan Kimia, 3,(1 ) (2009), $404-412$.

[11]Sartika.B.S. 2012. Pengaruh Penerapan Metode Eksperimen Sebagai Implementasi Kurikulum Tingkat Satuan Pendidikan (KTSP) terhadap Prestasi Belajar Siswa. Pedagogia, 1 (2) (2012) 